\title{
Revisiting Issues Relating to the Content of Ownership Rights, as Exemplified By the Legislation of Russia and other Countries
}

\author{
Sergey S. Bondarenko ${ }^{1,{ }^{*}}$, Anna V. Mikhnevich ${ }^{2}$, Sergey V. Tychinin ${ }^{1}$, Evgeny E. Tonkov ${ }^{1}$ \\ and Evgeny I. Chesovskoy ${ }^{1}$ \\ ${ }^{1}$ Belgorod National Research University, 85 Pobedy Street, Belgorod, 308015, Russian Federation \\ ${ }^{2}$ Kuban State Agrarian University Named after I.T. Trubilin, 13 Kalinin Street, Krasnodar, 350044, Russian \\ Federation
}

\begin{abstract}
Given article takes into consideration the approaches to the disclosure of the ownership rights content existing in different legal systems. The idea of disclosing the ownership rights content through a specific set of owner's powers exists in the legal systems of various countries. In this case, the number of legal powers may differ, as well as an understanding of each of them. The triad of owner's powers (possession, use, disposal), enshrined in the laws of Russia and a number of other countries, is analyzed in details. The views regarding the construction of a theoretical model of the content of ownership rights were expressed.
\end{abstract}

Keywords: Ownership right, proprietary rights, possession, use, disposal.

\section{INTRODUCTION}

It is customary to disclose the content of the ownership right through a specific set of proprietary rights. This tradition dates back to Roman law, and more precisely in the writings of medieval commentators of Roman law - glossators who emphasized the right to use a thing (jus utendi), the right to receiving the results of one's labor, income (jus fruendi) and the right to dispose (jus abutendi). This approach to the disclosure of the ownership rights content has gained great fame, and it is recognized as correct by some key opinion leaders (Colin et al., 1957).

One or another set of proprietary rights is enshrined in many foreign civil codes. For example, Art. 544 of the French Civil Code of 1804 declares the right to use and dispose of things; Art. 206 of the Civil Code of Japan in 1898 declares the right to use a thing, to obtain benefits and disposals; Art. 1228 of the Civil Code of Brazil in 2003 declares the right to consume, use and dispose of one's thing and the right to claim things from another's illegal possession or holding. Art. 39 of the Property Rights Law of the People's Republic of China 2007determines the main content of the ownership right through the rights of ownership, use, profit and disposal.

The idea of allocation the set of proprietary rights is not uncommon to English and American lawyers. In

*Address correspondence to this author at the Belgorod National Research University, 85 Pobedy Street, Belgorod, 308015, Russian Federation;

E-mail: sun.vandre@gmail.com this regard, they often refer to the work of the English scientist $A$. Honore, who counted 11 powers of the owner (Honore, 1961). We believe that here we are talking about the original author's concept, so this approach is not indicative. Here is what the American lawyer W. Burnham writes about the content of the ownership rights: "The content of property rights is constituted by the rights and obligations of citizens in relation to things. The whole set of such rights and obligations is often compared with a bunch of sticks, each "stick" corresponding to a specific right: (1) the right to own, (2) accommodation right, (3) the right to eliminate third party interference and (4) the right to convey (sale)" (Burnham, 2006).

\section{MATERIAL AND METHODS}

We used the dialectical, historical, comparative legal and formal legal methods in this paper. We made an attempt to systematically examine the research subject. We made the conclusions on the basis of the comparative law method.

\section{RESULTS AND DISCUSSION}

In the legislation of Russia, the content of the ownership right is customarily detected through of proprietary rights (possession, use, and disposal). This tradition has deep roots. For the first time, the three above mentioned powers were enshrined in Art. 420 book 2, volume 10 of the Code of Laws of the Russian Empire in 1832. It is widely known that the development of the Russian Empire Code of Laws was conducted by an outstanding lawyer and statesman M.M. Speransky. In this regard, possession, use and 
disposal in the scientific literature are sometimes referred to as the Speransky's triad. However, the idea of distinguishing the three owner's powers considered was expressed before M.M. Speransky. One of the first Russian civilists V.G. Kukolnik in his work of 1813 proposed the following definition: "Possession, or in other words, ownership of a property is the right in a thing, from which it follows the power to own the thing, use it and arbitrarily dispose entire thing, or only a part of it, if State Law or the right of another person is not an impediment" (Kukolnik, 1813: 98). With the legislative consolidation of the triad, the idea of its universality and inclusiveness simultaneously arose. Here is how this idea was expressed by another famous Russian civilist of the XIX century D.I. Meyer: "All possible actions of the owner regarding a thing can be summed up to possession, use or disposal, so the very right of ownership can be determined by the bundle of the ownership right, accommodation right and disposal right" (Meyer, 1859: 6).

The triad of owner's powers was presented in detail in the draft Civil Code of the Russian Empire in 1905, where a separate article was dedicated to each of the powers (Articles 756-758). Henceforth, the triad was presented in all codifications of Russian civil legislation: the Civil Code of the RSFSR in 1922 (Article 58), the Civil Code of the RSFSR in 1964 (Article 92), as well as in the current Civil Code of the Russian Federation in 1994 (Article 209).

The owner's powers read in conjunction (possession, use and disposal) can be found in the legislation of most countries in the post-Soviet space. And this applies both to countries whose civil codes are based on the Model Civil Code for the CIS member states (Article 163 of the Civil Code of the Republic of Armenia, Article 210 of the Civil Code of the Republic of Belarus, Article 188 of the Civil Code of the Republic of Kazakhstan, Article 222 of the Civil Code of the Kyrgyz Republic, Article 232 of the Civil Code of the Republic of Tajikistan), as well as of those countries that have chosen their own way of codifying civil legislation (Article 315 of the Civil Code of the Republic of Moldova, Article 317 of the Civil Code of Ukraine). The three traditional powers of the owner were added by the power "to demand the elimination of any violations of his property right, no matter who they come from" in the Civil Code of the Republic of Uzbekistan (Article 164). The Civil Code of Georgia (Art. 170) and the Civil Code of Turkmenistan (Art. 191) supplemented the triad with the power "not to allow ownership of this property by other persons".
Civil codes of Belarus, Russia, Uzbekistan, and Ukraine only itemize the powers of the owner. Civil codes of Azerbaijan, Armenia, Kazakhstan, Kyrgyzstan, and Tajikistan also establish legal definitions of each of the powers. It is interesting to note that these definitions almost literally coincide. The right of ownership means a legally secured opportunity to exercise de facto enjoyment of the property. The right of use is a legally secured opportunity to extract its useful natural properties from the ownership, as well as to receive benefits from it, including income, increments, fruits, and offspring. The disposal right is interpreted as a legally secured opportunity to establish the legal destiny of asset. The civil codes of Georgia, Azerbaijan and Turkmenistan do not provide legal definitions of the owner's eligibility, but they especially emphasize that the right to use also includes the possibility of a person not to use the asset.

The triad of owner's powers over the whole period of its existence had both supporters and opponents. For example, according to the famous pre-revolutionary Russian civilist G.F. Shershenevich opinion the indication of the powers of possession, use and disposal in the law could not be considered successfully primarily because "it is impossible to enumerate all the individual powers that are part of the right of ownership, and the law missed indicating the right to destroy things(Shershenevich, 1914: 280). In the Soviet period, A.V. Venediktov was one of the most authoritative opponents of the triad, he believed that "individual powers of the owner: the right to own, use and dispose a thing - neither separately, nor in combination ... do not express either the entire volume of the ownership right or the essence of the ownership right" (Venediktov, 1948: 31). D.M. Genkin disagreed with him, and believed that "the legal right of ownership is fully determined by the powers of possession, use and disposal" (Genkin, 1961: 56). There has been speculation around the triad in modern Russian civilistics. So, according to K.I. Sklovsky, the triad of powers is a sign of restriction of ownership, the detection of its inferiority. Therefore, it is necessary to pivot from the triad, to approach the right of ownership not as a set of powers, but as the most complete right in general (Sklovsky, 2000: 125-126). N.N. Averchenko responds, that "the triad is formulated so successfully that it incorporates any possible options for the owner and at the necessary level of abstractness".

The proposals to reform the triad, add some new powers to it sounded repeatedly. Accordingly, it is widely-known that during the development of the 
Russian Federation Civil Code in 1994 it was discussed the idea of securing the power to manage property along with the traditional powers of the owner. But the developers did not go this way, believing that management can be considered as an integral part of the disposal legal capacity (Khokhlov, 1998: 386). In Russian legal literature, at different times there were proposals to supplement the triad with the right to own a business (Vitryansky \& Gerasimenko, 1993: 53), the right to receive fruits of labor and incomes (Alexandrina, 2002: 11), and the right of access to things (Volochay, 2015). Such proposals can hardly be considered promising. As it was correctly noted by K.I. Sklovsky: "the most sophisticated and yet always more or less vulnerable argumentation is required in order to prove the possibility of inclusion the power in the ownership right which is not identifiable with one of the triad's elements" (Sklovsky, 2000).

Evaluating the triad, it is necessary to pay attention to the fact that the powers included in it, in turn, are not homogeneous. The power of possession is manifested in the ability of the owner to keep a thing in his (in his household), to have constant access to it, to take protective measures. The power of use covers all sorts of possibilities for using a thing (including production activities), extracting fruits of labor and incomes, and consuming a thing. Some scientists believe that consumption should be attributed to the simultaneous implementation of both the power of use and the power of disposal (Korneev, 1964). The power of the disposal implies the possibility of performing both legal actions (various transactions with the thing) and actual actions (for example, targeted destruction of the thing by the owner). In this regard, O.S. loffe proposed to distinguish between legal and actual actions (loffe, 1967: 359).

Considering the internal heterogeneity of every power, it is not difficult to turn the triad of the owner's powers (possession, use, and disposal) into a tetralogy (for example, possession, use, consumption, and disposal); in the pentad (for example, possession, use, consumption, disposal, destruction) or some other more complex set. Thus, the question is not how many powers to allocate, but how to understand each of the allocated powers. There is a tradition in Russian civil science to interpret each of the three powers as widely as possible, due to which almost any action of the owner in relation to a thing can be brought either under possession, or under use, or under disposal. Therefore, the triad of the owner's powers seems quite successful and universal. But, of course, this does not mean that the triad is the only possible option for disclosing the content of the ownership right.

From our perspective, the triad of ownership rights existing in the legislation should hardly serve as a starting point for theoretical pattern making of the ownership right content. For these purposes, we should turn to the general theory of law. It is widely known that the content of any legal right is constituted by certain powers (legally secured opportunities). It is universally recognized that there are two powers: powers for one's own active actions and powers to demand certain behavior (performing certain actions or abstaining from certain actions) from other persons (loffe \& Shargorodsky, 1961: 223; Halfina, 1974: 226-227). Many scientists also propose to allocate the third power - the power to be protected (Alekseev, 1982: 118-125; Sukhanov, 2011: 113; Bondarenko et al., 2018). It is necessary to build upon the disclosure of the content of ownership rights from these general theoretical postulates. It is easy to notice that possession, use and disposal only relate to the right to own active actions. With such a consideration, the traditional triad is not authority, but sub-authority, revealing the owner's authority to his own active actions. This circumstance has already been noticed in the literature (Vlasova, 1998: 20, 43-44). The power to demand a certain behavior for the owner manifests itself in the possibility of requiring others to refrain from certain actions (for example, not to go through the owner's unfenced land). As long as it is allocated the power to be protected, regarding to the right of ownership means the possibility of filing a vindication claim, a negative claim, other legal claims, the possibility of using the administrative procedure for protection and the use of self-defense methods.

\section{CONCLUSIONS}

The idea of detecting the content of the ownership right through one or another more or less wide range of powers is presented in various legal systems. In Russian legislation and in most other countries of the post-Soviet space, the triad of the ownership rights is traditionally allocated - possession, use and disposal. This tradition has deep roots and deserves respect. The triad is very successful and universal, but it is not the only possible option for disclosing the content of ownership rights. The model making that describes the content of ownership rights with a sufficient degree of completeness and scientific abstractness is one of the most important tasks of the theoretical understanding of ownership rights. 


\section{REFERENCES}

Alekseev, S.S. (1982). General Theory of Law: In 2 vols. Vol. II. Moscow: Legal literature, 360 p. (in Russian)

Alexandrina, M.A. (2002). The content of property rights under modern Russian legislation: some problems of theory and legal regulation. Dis. ... cand. legal sciences. Volgograd, 221 p. (in Russian)

Bondarenko, S. S., Barashyan, L. R., Goltsov, V. B., Korobko, K. I., \& Tychinin, S. V. (2018). The institute for damage prevention in the civil law of the member states of the Commonwealth of Independent States.

Burnham, W. (2006). Introduction to the law and legal system of the United States. St. Paul: Thomson/West.

Colin, A., Capitant, H., \& de La Morandière, L. J. (1957). Traité de droit civil: de Ambroise Colin et Henri Capitant... refondu par Léon Julliot de La Morandière,... Tome 1er. Introduction générale. Institutions civiles et judiciaires, personnes et famille. Dalloz.

Genkin, D.M. (1961). Ownership in the USSR. Moscow, State Publishing House of Legal Literature, 223 p. (in Russian)

Halfina, R.O. (1974). General Doctrine of legal relationship. Moscow: Legal literature, $351 \mathrm{p}$. (in Russian)

Honore, A. M. (1961). Ownership. Oxford essays in jurisprudence. Oxford: 107-147.

loffe, O.S. (1967). Soviet civil law. Moscow: Legal literature, $494 \mathrm{p}$. (in Russian)

loffe, O.S., \& Shargorodsky, M.D. (1961). Questions of the theory of law. Moscow: Legal literature, 381 p. (in Russian)
Khokhlov, S.A. (1998). Ownership and other property rights. Civil Code of Russia: Problems. Theory. Practice: Collection of memory S.A. Khokhlov / Resp. ed. A.L. Makovsky. Moscow: International Center for Financial and Economic Development, 480 p. (in Russian)

Korneev, S.M. (1964). The right of state socialist property in the USSR. Moscow: Publishing house of Moscow University, 268 p. (in Russian)

Kukolnik, V.G. (1813). Initial foundations of Russian private civil law. St. Petersburg: Senate Printing House, 240 p. (in Russian)

Meyer, D.I. (1859). Ownership under Russian civil law. St. Petersburg, 142 p. (in Russian)

Shershenevich, G.F. (1914). Textbook of Russian civil law. Volume 1. Moscow, Edition of the Bashmakov Brothers, 483 p. (in Russian)

Sklovsky, K.I. (2000). Property in civil law: a practical training manual. 2nd ed. Moscow: Delo, 512 p. (in Russian)

Sukhanov, E.A. (2011). Russian civil law: Textbook: In 2 vol. T. I. 2nd ed., Stereotyped. Moscow: Statut, 958 p. (in Russian)

Venediktov, A.V. (1948). State socialist property. Moscow, Leningrad, Publishing House of the Academy of Sciences of the USSR, 839 p. (in Russian)

Vitryansky, V.V., Gerasimenko, S.A. (1993). Arbitration and judicial practice. A comment. Moscow, 216 p.(in Russian)

Vlasova, A.V. (1998). The structure of subjective civil law. Yaroslavl, 116 p. (in Russian)

Volochay, Yu.A. (2015). Protection by the owner of the right of access to his property. Russian Journal of Law, 4, 81-87. (in Russian)

\section{DOI: https://doi.org/10.6000/1929-4409.2020.09.84}

(C) 2020 Bondarenko et al.; Licensee Lifescience Global.

This is an open access article licensed under the terms of the Creative Commons Attribution Non-Commercial License (http://creativecommons.org/licenses/by-nc/3.0/) which permits unrestricted, non-commercial use, distribution and reproduction in any medium, provided the work is properly cited. 